\title{
Assessment of the Environmental Impacts of Solous Municipal Solid Waste Landfills using Soil Properties and Earthworms (Eudrilus eugeniae)
}

\author{
AMADI, CS; ANIKWE, JC; *OBANYA, HE; OKOROAFOR, CU
}

\author{
Department of Zoology, University of Lagos, Akoka, Nigeria.
}

*Corresponding Author Email: henryobanya@ rocketmail.com

\begin{abstract}
This study assessed the effects of Solous Municipal Solid Waste Landfills on soil properties, heavy metal contamination and macro-invertebrates (earthworms). Soil and earthworm samples were collected from Solous municipal solid waste landfills with reference samples obtained from the Botanical Garden, University of Lagos and taken to the laboratory for analyses using standard methods. Results showed that $\mathrm{pH}$ and organic matter values of soil samples from the landfills ranged from $8.51 \pm 0.88$ to $9.85 \pm 0.02$ and $5.79 \pm 0.53 \%$ to $7.11 \pm 1.19 \%$ respectively, and they were statistically $(P<.05)$ higher than the values of the reference samples. Most of the assessed heavy metals in soil and earthworms from the landfills were significantly $(P<.05)$ higher when compared to the reference samples. The antioxidant enzymes and lipoperoxidation product levels were significantly $(P<.05)$ higher in earthworms from most of the landfills in relation to the reference samples. The mean total protein concentrations in annelids from the landfills were lower than the mean concentration in the reference samples, however, only those from two of the landfills (Solous B and C) were significant $(P<.05)$. Histological studies showed that the clitella of earthworms from the landfills had abnormalities such as disruption of body wall muscle layers, cellular degeneration, oedematous longitudinal muscle, and dark brown pigments. Solous Landfills had an obvious effect on the assessed abiotic and biotic parameters, and could be a source of heavy metal pollution in nearby vicinities especially their groundwater sources and surface water.
\end{abstract}

\section{DOI: https://dx.doi.org/10.4314/jasem.v23i2.18}

Copyright: Copyright $\odot 2019$ Amadi et al. This is an open access article distributed under the Creative Commons Attribution License (CCL), which permits unrestricted use, distribution, and reproduction in any medium, provided the original work is properly cited.

Dates: Received: 30 December 2018; Revised: 11 January 2019; Accepted 19 January 2019

Keywords Biochemical markers, Bioindicator, Eudrilus eugeniae, Heavy metals, Landfill, Soil properties.

Waste management operations in many Nigerian cities such as Lagos involve landfilling which is the simplest and cheapest mode of municipal waste disposal, followed by incineration of the municipal solid wastes (Barrett and Lawlor, 1995). The practice of incineration of municipal solid wastes has contributed to the gradual depletion of the ozone layer, global warming, and has also affected the quality of the local air (WHO, 1996). Leachate formed as a result of percolation of rainfall and moisture through wastes in landfills contains various contaminants and toxic substances especially heavy metals which can descend into the soil profile and contaminate the adjacent surface water and groundwater system (Christensen $e t$ al., 2001). Due to the toxicity and nonbiodegradability of heavy metals, their introduction into the environment poses a serious threat to life and unlike other kinds of pollution (atmosphere and water), the soil environment has a much lower ability to recover (Aina et al., 2009; Odoh et al., 2011). The effects of heavy metals depend on their bioavailability and they have been extensively studied for their consequences on human health. Exposure to lead has been reported to cause mental retardation in children, kidney failure, anaemia and may possibly result in lung cancer (Singh et al., 2011; Steenland and Boffetta, 2000). Cadmium is a priority environmental contaminant because it induces kidney damage and causes cancer (IARC, 2012). Copper, zinc, nickel, and chromium have been studied to have adverse effects such as damage to the nervous membrane, kidney and liver failure, cancer, and fatigue (Jaishankar et al., 2014). There is, therefore, a need for continuous monitoring of the level of heavy metals in landfills as well as its immediate impacts on the soil biota, humans and the ecosystem generally in order to keep a check on the environment and to provide data for future research works.

Lagos State health and environmental officials acknowledge that most of the garbage and sewage collected by private operators, as well as the effluents from industries end up in the lagoons and creeks (Jideonwo, 2014). Much of the rest is burnt either in numerous illegal open dumps in the city or in the official landfills operated by the government of which Solous Landfills, Igando, are among. The aim of the study was to assess the impacts of Solous Municipal Landfills on soil properties, heavy metal contamination and macro-invertebrates (earthworms). 


\section{MATERIALS AND METHODS}

Site Description: The three landfills known as Solous 1 (closed), Solous 2 (open) and Solous 3 (open) are in Solous Community, Alimosho, Lagos, Nigeria. Solous 1/A (N06 ${ }^{0} 34.3$ 07', E00 $3^{0} 1$ 5. 211'), Solous 2/B

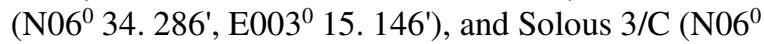
\left. 33. 897', ${\mathrm{E} 003^{\circ}}^{0} 15.082^{\prime}\right)$ cover about 7.8, 3.2 and 5 hectares of land respectively (Longe and Balogun 2010) (Fig. 1). These landfills are surrounded by commercial and industrial establishments as well as a clustered human settlement. The types of wastes in Solous Landfills are organic and inorganic. The landfills are non-engineered and do not undergo waste sorting. The typical views of Solous A, B and C are shown in Plates 1a-c respectively.

Sample Collection: Soil samples and earthworms from the landfills were collected in August 2017 approximately 25 metres apart in each case from four (4) stations within each of the landfills and were tagged Station 1, Station 2, Station 3, and Station 4. The Botanical Garden of the University of Lagos was used as the reference site. At each sampling station, the surface debris was removed and the subsurface soil dug to a depth of between 1 and $15 \mathrm{~cm}$ with a spade. About $50 \mathrm{~g}$ of soil from each station was taken into a plastic container and labelled. Soil samples were allowed to dry at room temperature for 14 days and passed through a $2 \mathrm{~mm}$ sieve.

Earthworms (Eudrilus eugeniae) were collected by digging into the soil and hand sorting within the quadrant and then placed in sample bottles and labelled. Earthworms were washed with distilled water. The earthworms were placed in decontaminated glass jars. Earthworms were refrigerated overnight to allow time to purge the soil in the guts (Bamgbose $e t$ al., 2000).

Analyses of Samples: Analyses of samples were done according to the method described by Bamgbose et al., (2000). $5 \mathrm{~g}$ of sieved soil sample was weighed, $10 \mathrm{ml}$ concentrated nitric acid was added and digested over a hot plate for 2 hours.

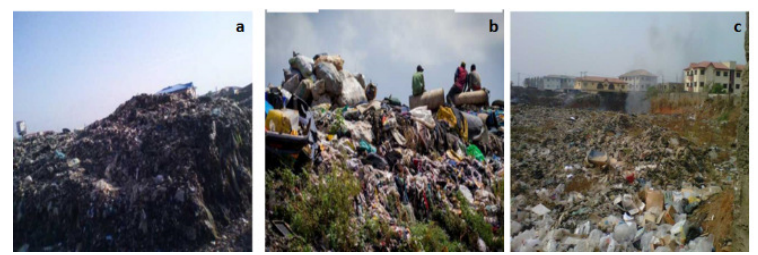

Plates 1a-c: Views of a- Solous A Landfill, Igando, Alimosho, Lagos, Nigeria. b- Solous B Landfill, Igando, Alimosho, Lagos, Nigeria. c- Solous C, Igando, Alimosho, Lagos, Nigeria.

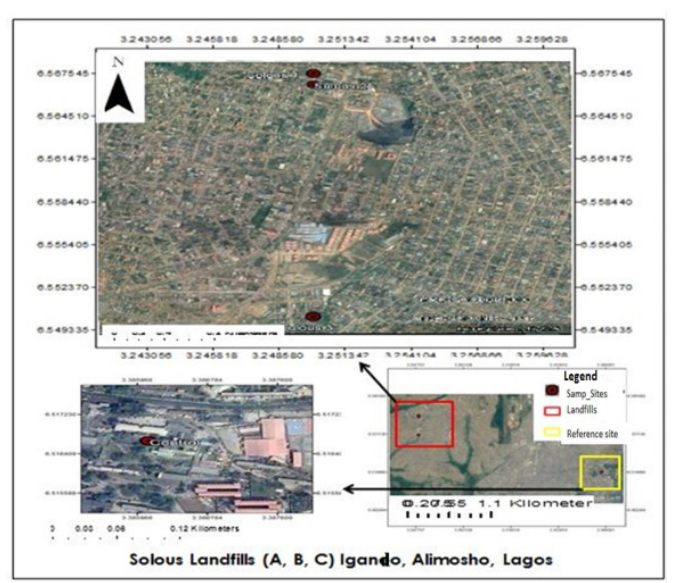

Fig 1: Map presentation of the three Solous Landfills (A, B and C), Igando, Alimosho, Lagos, Nigeria.

The suspension was filtered and the solution was made up to $25 \mathrm{ml}$ with distilled water in a volumetric flask. Metals were estimated using Agilent 240AA Atomic Absorption Spectrophotometer. A blank determination was also carried out using the above procedure to correct for contamination and impurities. $3 \mathrm{~g}$ of defrosted earthworm was measured and macerated using a previously cleaned and decontaminated laboratory mortar. Metals in the tissues were extracted using $2 \mathrm{ml}$ of concentrated nitric acid. It was then heated to dryness on a hot plate and the digest was re-dissolved in $1 \mathrm{ml}$ concentrated nitric acid and made up to $50 \mathrm{ml}$ with distilled water in a volumetric flask. Agilent 240AA Atomic Absorption Spectrometer was used for the determination of all the elements.

Biota-to-soil Accumulation Factor: The biota-to-soil accumulation factor (BSAF) of the metals in the earthworms was calculated as the ratio of the mean metal levels in Eudrilus eugeniae to the mean metal levels in soil sample in accordance with the formula adopted by Dai et al., (2004).

Analyses of Soil Properties: The procedure adopted by Owagboriaye et al., (2015) was used for the determination of percent organic matter. $0.5 \mathrm{~g}$ of airdried soil was weighed into a $100 \mathrm{ml}$ conical flask, then $5 \mathrm{ml}$ potassium dichromate solution was added. $10 \mathrm{ml}$ concentrated sulphuric acid was immediately added. This was mixed by swirling the flask for about a minute and left to stand for 30 minutes on a glass plate. $100 \mathrm{ml}$ distilled water was then added followed by addition of 3-4 drops of ferroin indicator. The solution was titrated with $0.5 \mathrm{~N}$ ferrous sulphate solution until the colour changed from deep green through bright green to reddish brown (maroon). A blank was carried out through the procedure to correct for impurities from reagent and contamination during 
the process. The percentage organic carbon is given by the following equation.

$\underline{\left(\mathrm{MeK}_{2} \mathrm{Cr}_{2} \mathrm{O}_{7}-\mathrm{MeFeSO}_{4}\right) \times 0.0031 \times 100 \times \mathrm{F}}$ Mass (g) of air-dried soil

$\mathrm{F}=$ Correction factor (1.33); $\mathrm{Me}=$ Normality of solution $\times \mathrm{ml}$ of solution used

$\%$ organic matter in soil $=\%$ organic carbon $x 1.729$.

Soil $\mathrm{pH}$ was determined according to the method of Bamgbose et al., (2000).

Biochemical Studies: Activities of superoxide dismutase (SOD), catalase (CAT), malondialdehyde (MDA) levels and protein concentration were determined according to the methods employed by Ifemeje et al., (2015).

Histological Studies: The histological studies were done according to the protocol described by Otitoloju et al., (2009).

Statistics: For all the parameters tested, comparisons of means were analysed statistically using one-way Analysis of Variance (ANOVA).The Post-hoc test was also carried out to determine the significant differences at $P<.05$ using Least Squared Difference (LSD). The relationships between the soil and earthworm samples were established using the Pearson Correlation index. All statistical analyses were performed using SPSS 20 (IBM).

\section{RESULTS AND DISCUSSION}

Soil Properties: The $\mathrm{pH}$ values of soil samples from the landfills ranged from $8.51 \pm 0.88$ to $9.85 \pm 0.02$, and they were statistically $(P<.05)$ higher than the soil $\mathrm{pH}$ of the reference site (Table 1).

Percentage organic matter of soil samples from the landfills varied between $5.79 \pm 0.53 \%$ and $7.11 \pm 1.19$ $\%$, and they were significantly $(P<.05)$ higher when compared to the reference site.

Table 1 Soil $\mathrm{pH}$ and percentage organic matter of soil samples

\begin{tabular}{lll} 
& \multicolumn{2}{c}{ from study sites } \\
\hline Study Site & Soil $\mathbf{~ p H}$ & $\begin{array}{l}\text { Percentage } \\
\text { Matter }(\%)\end{array}$ \\
\hline Reference site & $6.36 \pm 0.54$ & $3.34 \pm 1.22$ \\
Solous A & $9.85 \pm 0.02^{*}$ & $5.79 \pm 0.53^{*}$ \\
Solous B & $9.47 \pm 0.42^{*}$ & $6.31 \pm 0.57^{*}$ \\
Solous C & $8.51 \pm 0.88^{*}$ & $7.11 \pm 1.19^{*}$ \\
$*$ denotes values that are significantly $(P<.05)$ different from the \\
\multicolumn{3}{c}{ reference site }
\end{tabular}

Heavy metals: Figure 2a depicts the mean levels of heavy metals in soil samples from the reference site and landfills. Hg levels in the soil samples from the landfills varied between $39.95 \pm 12.68$ and $63.99 \pm 10.42$ $\mathrm{mg} / \mathrm{kg}$, and they were statistically $(P<.05)$ higher when compared to the reference site. $\mathrm{Zn}$ levels in the reference site were lower than those in the landfills, however, only the $\mathrm{Zn}$ level in Solous A was significantly $(P<.05)$ different. Mean $\mathrm{Pb}$ level in Solous A was significantly $(P<.05)$ higher than the reference site. $\mathrm{Pb}$ levels in Solous $\mathrm{B}$ and $\mathrm{C}$ were also higher but not significant $(P=.123$ and $P=.056$ respectively). The mean levels of $\mathrm{Cu}, \mathrm{Mn}$ and $\mathrm{Cd}$ in the landfills varied from $31.08 \pm 4.65$ to $54.14 \pm 9.24$ $\mathrm{mg} / \mathrm{kg}, 100.64 \pm 27.93$ to $114.15 \pm 24.96 \mathrm{mg} / \mathrm{kg}$, and $4.34 \pm 1.02$ to $5.73 \pm 1.34 \mathrm{mg} / \mathrm{kg}$ respectively, and they were markedly $(P<.05)$ higher in relation to the reference site.

Figure $2 b$ illustrates the mean concentrations of metals in earthworms from the landfills and reference site. $\mathrm{Hg}$ levels were between $34.90 \pm 14.79 \mathrm{mg} / \mathrm{kg}$ and $59.23 \pm 10.42 \mathrm{mg} / \mathrm{kg}$ in earthworms from the landfills and they were significantly $(P<.05)$ higher. The concentration trend of $\mathrm{Zn}$ in earthworms was reference site < Solous A < Solous C < Solous B. Mean Zn level in earthworms from Solous B was statistically $(P<$ $.05)$ higher. $\mathrm{Pb}$ levels in earthworms from the landfills varied from $109.93 \pm 54.99$ to $134.99 \pm 27.99 \mathrm{mg} / \mathrm{kg}$, and they were significantly $(P<.05)$ higher than the reference site. The mean levels of $\mathrm{Cu}, \mathrm{Mn}$, and $\mathrm{Cd}$ in the landfills ranged from $27.34 \pm 4.22$ to $61.09 \pm 22.92$ $\mathrm{mg} / \mathrm{kg}, \quad 84.30 \pm 15.95$ to $112.20 \pm 20.36 \mathrm{mg} / \mathrm{kg}$, and $5.52 \pm 1.62$ to $4.16 \pm 0.92 \mathrm{mg} / \mathrm{kg}$ respectively. Levels of $\mathrm{Mn}$ and $\mathrm{Cd}$ in earthworms from the landfills were markedly $(P<.05)$ higher.

The BSAF values of the metals are presented in Table 2 . The values were mostly below 1 except for $\mathrm{Cd}$.
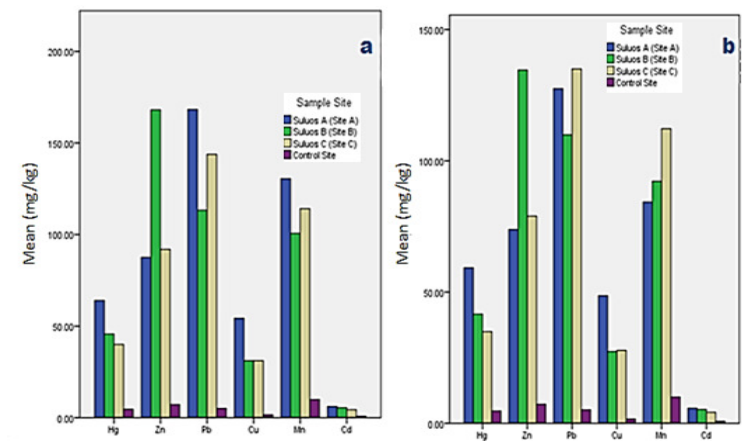

Fig. 2a\&b: a- Heavy metal concentrations in soil samples; bHeavy metals concentrations in earthworms

Heavy Metal Contents of the Earthworms in Relation to Metal Contents of the Soil: The Pearson's correlation showed there was a strong positive correlation $(\mathrm{P}=0)$ between the levels of heavy metals $(\mathrm{Hg}, \mathrm{Zn}, \mathrm{Cu}, \mathrm{Cd}, \mathrm{Pb}$ and $\mathrm{Mn}$ ) in soil and those in earthworms from the landfills (Table 3). 
Several factors influence the properties of soil (Yanai et al., 2003). In this study, the soil organic matter (SOM) and $\mathrm{pH}$ of the landfills were higher than the reference site. This suggests that wastes in the landfills significantly influence the properties of the soil. The decomposition of organic wastes leads to an increase in the organic matter content of the soil (Seçer et al., 2016). This is in agreement with the present findings that showed that the percent organic matter values in the soil samples from the landfills were higher than the reference site. The retention of chemicals in the soil is regulated by soil properties such as SOM (Kavamura and Esposito, 2010). Heavy metals are retained by SOM (Elaigwu et al., 2007). This means that soil with a high SOM content has a high retention ability of heavy metals. This was confirmed by the high levels of heavy metals in the landfills. Generally, the assessed heavy metals in soil samples and earthworms from the landfills were higher when compared to the reference site. This indicates that there is a significant metal contamination of the soil of the landfills by the wastes. Wastes that contain heavy metal could have contributed to the high levels of metals in the landfills as reported by (Aucott, 2006). Additionally, incineration of wastes which is a common practice in the landfills contributes to the heavy metal content of the soil. Incineration makes the metals soluble by oxidation which thereafter leach into the soil (Ukpong et al., 2013). These metals do not stay in the landfills endlessly. Studies have shown that leachates from landfills containing heavy metals may find their way into the groundwater sources thereby contaminating the source of drinking water for humans (Alborés et al., 2000; Okoronkwo et al., 2005). Based on the bioaccumulation studies, the high biota-soil accumulation factor (BSAF) values of $\mathrm{Cd}$ indicate that it could be the most mobile and bioavailable of the assessed metals in the soil of the landfills. This corroborates the study of Nannoni et al., (2011) who reported that $\mathrm{Cd}$ is more mobile than $\mathrm{Cu}, \mathrm{Pb}$, and $\mathrm{Zn}$. In addition to the bioaccumulation studies, the correlation results indicated that there was a strong positive relationship between the levels of metals in the soil and earthworms, suggesting that the levels of metals in the soil are directly proportional to the levels in earthworms. This could be additional information to the bioaccumulation studies indicating that the earthworms have the ability to take up heavy metals from the soil.

Table 2 Biota-to-soil accumulation factors (BSAF) of the metals in

\begin{tabular}{lllllll}
\multicolumn{7}{c}{ earthworms } \\
\hline Sites & Hg & Zn & Pb & Cu & Mn & Cd \\
\hline Control & 1.02 & 1.01 & 1.00 & 1.03 & 0.12 & 1.04 \\
Solous A & 0.93 & 0.84 & 0.76 & 1.13 & 0.46 & 1.06 \\
Solous B & 0.91 & 0.80 & 0.97 & 0.88 & 0.91 & 1.05 \\
Solous C & 0.87 & 0.86 & 0.94 & 0.89 & 0.98 & 0.96 \\
\hline
\end{tabular}

Table 3 Correlations between the levels of metals in the soil and earthworms

\begin{tabular}{cll}
\hline $\begin{array}{l}\text { Heavy } \\
\text { Metal }\end{array}$ & $\begin{array}{l}\text { Correlation } \\
\text { Coefficient }\end{array}$ & $\begin{array}{l}\text { Sig. } \\
\text { Value }\end{array}$ \\
\hline $\mathrm{Hg}$ & $0.982^{* *}$ & 0.000 \\
$\mathrm{Zn}$ & $0.975^{* *}$ & 0.000 \\
$\mathrm{~Pb}$ & $0.891^{* *}$ & 0.000 \\
$\mathrm{Cu}$ & $0.986^{* *}$ & 0.000 \\
$\mathrm{Mn}$ & $0.847^{* *}$ & 0.000 \\
$\mathrm{Cd}$ & $0.967^{* *}$ & 0.000 \\
\hline Correlation is significant at .01 level (2-tailed)
\end{tabular}

Biochemical Parameters: Superoxide dismutase (SOD) activities in annelids from the landfills were significantly $(P<.05)$ higher when compared to the control. The values varied between $4.88 \pm 0.54$ and $23.25 \pm 0.52 \mathrm{U} / \mathrm{mg}$ protein (Fig. 3a). With respect to the landfills, annelids from Solous $\mathrm{C}$ had the highest activity of SOD while Solous A had the lowest. Catalase (CAT) activities in the annelids from the landfills ranged from $0.0045 \pm 0.0051$ to $0.0355 \pm 0.006$ $\mathrm{U} / \mathrm{mg}$ protein (Fig. 3b). CAT activities in annelids from Solous A did not markedly $(P>.05)$ differ from the control. The lipoperoxidation product levels were markedly $(P<.05)$ higher in the annelids from the landfills when compared to the control. The values ranged from $0.12 \pm 0.03$ to $6.73 \pm 0.16 \mathrm{mg} / 100 \mathrm{~g}$ (Fig. $3 \mathrm{c})$. Mean total protein concentrations ranged from $1.54 \pm 0.26$ to $13.57 \pm 0.06 \mathrm{mg} / \mathrm{ml}$ (Fig. $3 \mathrm{~d}$ ). The mean total protein concentrations in annelids from the landfills were lower than those from the reference site, however, only Solous B and C were significantly $(P<$ $.05)$ different. Antioxidant enzymes such as superoxide dismutase (SOD) and catalase (CAT) are released when organisms are subjected to stress to eliminate free radicals or reactive oxygen species (ROS), thus resulting in the increase of the enzymes (Weydert and Cullen, 2010). On the other hand, when the stress becomes extreme the free radicals may inhibit the activities of the enzymes, which leads to the production of the lipoperoxidation product, malondialdehyde (MDA) (Onadeko et al., 2016). Higher levels of SOD, CAT and MDA were observed in earthworms from the landfills when compared to the reference samples in the present study, however, the difference was not significant for CAT activities. Results similar to the present findings were reported by Alani et al., (2017) who observed higher levels of MDA, SOD, and CAT in earthworms collected from Olusosun Landfill in relation to the reference site in their study. The ultimate product of oxidative stress, MDA, was higher in the earthworms from the landfills suggesting that they undergo a significant amount of stress. Further, it is important to combine several biomarker studies to ascertain the pollution status of an environment as done in the present study as it would help make a more-informed conclusion on the pollution status of the environment. The significant 
oxidative damage observed in this study may be responsible for the degradation of protein as it was observed that concentrations of proteins in earthworms from the landfills were lower when compared to the reference sample.
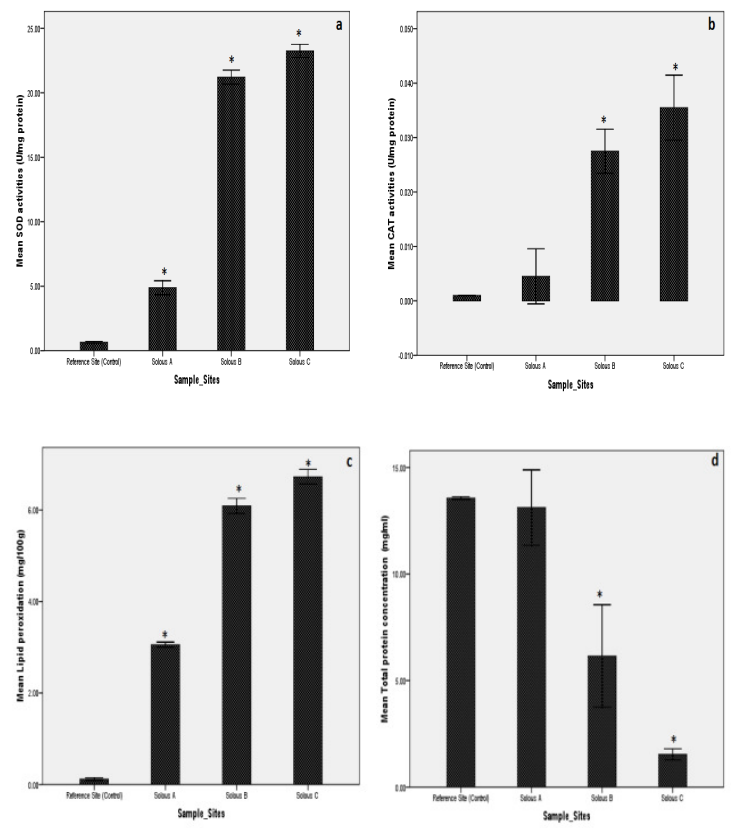

Fig. 3a-d. a- Mean activities of superoxide dismutase (SOD), bMean activities of Catalase (CAT), c- levels of lipid peroxidation product (Malondialdehyde-MDA), d- mean protein concentrations in Eudrilus eugeniae *significantly different from the control at $P<$ .05

Histopathology: The histological studies showed that the body wall muscle layers and internal viscera of the clitellum of E. eugeniae from the reference site were intact (Plate 2a). The earthworms from the landfills, unlike the reference sample, had histological alterations such as disruption of body wall muscle layers, cellular degeneration, oedematous longitudinal muscle, and dark brown pigments (Plates $2 \mathrm{~b}$-d). This is in agreement with the work of Alani et al., (2017) who observed histological abnormalities such as increased secretory activity, reduced body mass, and disorganized internal organ in the earthworms from Olusosun Landfill. Furthermore, the histology of Solous A sample showed minimal disruption of body wall muscle layers and loss of structural integrity of longitudinal and circular muscle suggesting that since the landfill is temporarily inactive, the earthworms in that site may have exhibited some level of repair.

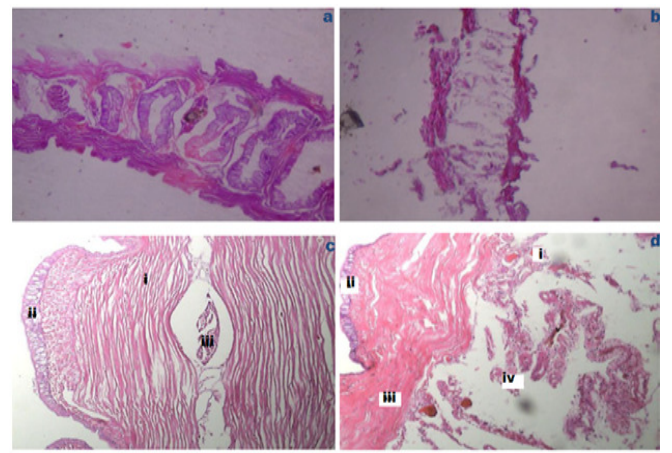

Plates 2a-d: Histological sections of the a- clitellum of E. eugeniae from the reference site showing intact body wall muscle layers and well outlined internal viscera $(\times 40)$. b- clitellum of E. eugeniae from Solous A showing a slight disruption of body wall muscle layers and loss of structural integrity of longitudinal and circular muscle. Internal viscera also not well outlined $(\times 40)$. c- clitellum of $E$. eugeniae from Solous B showing different abnormalities viz. cellular degeneration/reduction in thickness of epithelial layer (ii), oedematous longitudinal and circular muscle (i) and inter-muscular cell spaces (iii) $(\times 40)$. d- clitellum of E. eugeniae from Solous C, showing severe levels of different abnormalities viz. dark brown pigment (i), cellular degeneration (ii), oedematous longitudinal and circular muscle (iii) and inflammation of cells (iv) $(\times 40)$.

Conclusion: Landfilling could influence the properties of the soil by increasing the levels of soil $\mathrm{pH}$ and organic matter as shown in the present study. Landfilling also significantly contaminated the soil with metals and the major public health risk associated with this finding is the contamination of groundwater sources of nearby vicinities. The biochemical and histopathological results suggest that the macroinvertebrates inhabiting the landfills could be under severe environmental stress.

\section{REFERENCES}

Aina, M; Matejka, G; Mama, D; Yao, B; Moudachirou, M (2009). Characterization of stabilized waste; Evaluation of pollution risk. Int. J. Environ. Sci. Tech. 6(1): 159-165.

Alani, R; Akinsanya, B; Erhabor-Chimezie, M; Nwude, D (2017). Earthworm biomass as additional information for risk assessment of PCBs: A Case Study of Olusosun Dumpsite, Ojota, Lagos, Nigeria. American Journal of Life Sciences 5(3-1): 52-59.

Alborés, AF; Cid, BP; Gómez. EF; López, EF (2000). Comparison between sequential extraction procedures and single extractions for metal partitioning in sewage sludge samples. Analyst 125(7): 1353-1357.

Aucott, M (2006). The fate of heavy metals in landfills: A review. New York Academy of Sciences, New York. 
Bamgbose, O; Odukoya, OO; Arowolo, TOA (2000). Earthworms bioindicators of metal pollutions in dumpsite of Abeokuta city, Nigeria. Rev. Boil. Trop. 48 (1): 1-7.

Barrett, A; Lawlor J (1995). The economics of waste management in Ireland. Economic and Social Research Institute, Dublin.

Christensen, TH; Kjeldsen, P; Bjerg, PL; Jensen, DL; Christensen, JB; Baun, A (2001). Biogeochemistry of landfill leachate plumes. Appl. Geochem. 16: 659-718.

Dai, J; Becquer, T; Rouiller, JH; Reversat, G; Bernhard-Reversat, F; Nahmani, J; Lavelle, P (2004). Heavy metal accumulation by two earthworm species and its relationship to total and DTPA-extractable metals in soils. Soil Biology and Biochemistry 36(1): 91-98.

Elaigwu, SE; Ajibola, VO; Folaranmi, FM (2007). Studies on the impact of municipal waste dumps on surrounding soil and air quality of two cities in northern Nigeria. Journal of Applied Sciences 7(3): 421-425.

IARC (International Agency for Research on Cancer) (2012). Cadmium and cadmium compounds https://monographs.iarc.fr/wpcontent/uploads/2018/06/mono100C-8.pdf Accessed 20 December 2017.

Ifemeje, JC; Udedi, SC; Okechukwu, AU; Nwaka, AC; Lukong, CB; Anene, IN; Ezeude, IC (2015). Determination of total protein, superoxide dismutase, catalase activity and lipid peroxidation in soil macro-fauna (earthworm) from Onitsha Municipal Open Waste Dump. J. Sci. Res. Rep. 6(5): 394-403.

Jaishankar, M, Tseten T, Anbalagan N, Mathew BB, Beeregowda KN (2014). Toxicity, mechanism and health effects of some heavy metals. Interdisciplinary Toxicology 7(2): 60-72.

Jideonwo, JA (2014). Ensuring sustainable water supply in Lagos, Nigeria. Master of Environmental Studies Capstone Projects. https://repository.upenn.edu/cgi/viewcontent.cgi ?article $=1056 \&$ context $=$ mes_capstones. Accessed 19 December 2017.

Kavamura, VN; Esposito, E (2010). Biotechnological strategies applied to the decontamination of soils polluted with heavy metals. Biotechnology Advances 28(1): 61-69.

Longe, EO; Balogun, MR (2010). Groundwater quality assessment near a municipal landfill, Lagos, Nigeria. Research Journal of Applied Sciences, Engineering and Technology 2(1): 3944.

Nannoni, F; Protano, G; Riccobono, F (2011). Fractional and geochemical $f$ heavy elements in soil of a mining area in Nothern Kosovo. Geoderma 161(1-2):63-73.

Odoh, R; Agbaji, EB; Kagbu, JA; Thomas, SA (2011). Heavy metal speciation in agricultural farmland in some selected local government areas of Benue state, Nigeria. Archives of Applied Science Research 3(3): 560-573.

Okoronkwo, NE; Igwe, JC; Onwucheiewe, EC (2005). Risk and health implication of polluted soil for crop production. Afr. J. Biotechnol. 4(13):15201524.

Onadeko, AB; Amaeze, NH; Obe, MA (2016) Acute and chronic effects of lead nitrate and cadmium sulphate in tadpoles of Amietophrynus regularis (common African toad). The Bioscientist 4(1): 112.

Otitoloju, AA; Ajikobi, DO; Egonmwan, RI (2009) Histopathology and bioaccumulation of heavy metals $(\mathrm{Cu}$ and $\mathrm{Pb})$ in the giant land snail, Archachatina marginata (Swainson). Open Environ. Pollut. Toxicol. J. 1: 79-88.

Owagboriaye, FO; Dedeke, GA; Ademolu, KO; Adebambo, OA (2015). Bioaccumulation of heavy metals in earthworms collected from abattoir soils in Abeokuta, south-western Nigeria. The Zoologist 13: 36-42.

Seçer, M; Elmaci, ÖL; Ceylan, Ş (2016). The effects of organic wastes on soil and cotton quality with respect to the risk of boron and heavy metal pollution. International Journal of Agronomy 2016: 1-7.

Singh, R; Gautam, N; Mishra A; Gupta R (2011). Heavy metals and living systems: An overview. Indian J. Pharmacol. 43(3): 246-253.

Steenland, K; Boffetta, P (2000). Lead and cancer in humans: where are we now? Am. J. Ind. Med. 38: 29-59. 
Ukpong, EC; Antigha, RE; Moses, EO (2013). Assessment of heavy metals content in soils and plants around waste dumpsites in Uyo Metropolis, Akwa Ibom State. The International Journal of Engineering and Science 2(7): 75-86.

Weydert, CJ; Cullen JJ (2010). Measurement of superoxide dismutase, catalase and glutathione peroxidase in cultured cells and tissue. Nature Protocols 5(1): 51-66.
WHO (World Health Organization) (1996). Solid waste management in the pacific island countries, Western pacific region: Document series. http://www.wpro.who.int/environmental_health/ documents/docs/pacificguide.pdf. Accessed 20 December 2017.

Yanai, RD; Currie, WS; Goodale, CL (2003). Soil carbon dynamics after forest harvest: an ecosystem

paradigm 